\title{
MENUJU SUATU ESTETIKA YANG KRISTIANI
}

\author{
Jadi S. Lima \\ Sekolah Tinggi Teologi Reformed Injili Internasional
}

The madness of love is the greatest of heaven's blessings $\sim$ Plato

\begin{abstract}
ABSTRAK: Tulisan ini adalah suatu eksplorasi atas visi-visi tentang estetika sebagaimana didapati di dalam teori dan praktik sejak Plato sampai zaman Modern. Tujuan khusus yang ingin dicapai adalah menggali akar-akar dari identitas Kekristenan dan Ibrani sebagaimana kita dapat temui di dalam teks Alkitab dan praktik pada kedua tradisi. Perbandingan akan dilakukan antara visi Yunani tentang keindahan demi keindahan itu sendiri yang dianggap sakral, yang barangkali merupakan asal-muasal dari gerakan 'seni demi seni itu sendiri' ("l'art pour l'art") yang muncul di era Modern, dengan alternatif pada visi Ibrani tentang keindahan, yaitu keindahan sebagai respon terhadap kekudusan Allah dan kesenian sebagai sesuatu yang merujuk pada hal yang melampaui dirinya sendiri.
\end{abstract}

KATA KUNCI: Estetika, art for art, kesenian, Plato, Agustinus, Thomas Aquinas, Ibrani.

ABSTRACT: This is a historical, theological and philosophical exploration on some visions of aesthetics, as found in the works of Plato to the Modernists. My specific goal is to retrace the root of Judaism and Christian 
visions in aesthetics, especially as found in the Bible and practices in both traditions. I will compare Greek visions of beauty as valuable and sacred in itself - perhaps the root of l'art pour l'art movement in modern era, with the Hebrew vision of beauty as a response to the holiness of God - art as something that refer to something beyond itself.

KEYWORDS: Aesthetic, art for art, art, Plato, Agustinus, Thomas Aquinas, Hebrew.

\section{Pengantar}

Apakah cantik itu? Sesosok tubuh langsing, berkulit putih bersih (atau kecoklatan?), hidung mancung, sorot mata yang jernih dan ramah, bibir yang tipis kemerahan, anatomi tubuh seperti dewi Yunani? Seperti apa kelihatannya wanita yang paling cantik yang pernah lahir, jika anda membayangkannya? Jawaban yang muncul akan sangat beragam, tergantung siapa yang menjawab. Jika anda sering mengkonsumsi media populer Barat mungkin sosok seperti Sandra Bullock yang akan muncul. Jika anda berasal dari ras yang paling banyak jumlahnya di planet ini, mungkin sosok seperti Zhang Ziyi yang menjadi idaman anda. Jadi apakah cantik itu? Fenomena serupa terjadi ketika anda bertanya tentang yang indah dari sebuah lukisan, patung, musik, puisi, landscape, dan obyek seni lainnya. Jadi, apakah indah itu? Adakah kriteria mutlak bagi keindahan? Dapatkah seorang wanita tertentu dinobatkan sebagai mahluk paling cantik sejagat? Jika suatu ketika anda kagum melihat sebuah lukisan, dan kali berikutnya anda muak melihat lukisan yang sama, dapatkah lukisan itu dikatakan 
"indah?" Keindahan itu bersifat subyektif atau obyektif? Dapatkah kita mengalami perasaan/ pengalaman "keindahan" tanpa obyek? Jika kita mengingat-ingat sebuah lagu, dan kita menikmati lagu itu "di dalam kepala", dapatkah hal ini disebut "menikmati keindahan?" Beberapa karya seni modern dapat laku terjual amat mahal, tetapi orang yang tidak memahami nilainya akan sulit melihat perbedaannya dari coret-coretan anak Taman Kanak-Kanak. Apakah kita dapat menyusun pemahaman yang rasional untuk menjelaskan pengalaman keindahan, atau secara lebih umum, pengalaman estetik (keduanya tidak sama)? Lebih jauh lagi, bagaimanakah kita sebagai umat yang memiliki pengharapan di dalam Kristus Yesus, sebaiknya menjelaskan estetika? Bagaimanakah selama ini para pemikir Kristen memahami estetika? Bagaimanakah kita dapat terusmenerus diarahkan kepada kebenaran oleh suara-suara yang kita jumpai di dalam Alkitab dan perenungannya sepanjang zaman, dalam berbagai tradisi yang kaya, sepanjang sejarah?

\section{Dari Plato sampai Thomas Aquinas}

Konsep teoretis tentang keindahan mungkin pertama kali muncul di masa Yunani kuno dan kita masih dapat menemukan banyak pengaruhnya pada Abad Pertengahan. ${ }^{1}$ Secara umum bagi para pemikir seperti Plato, Pythagoras, dan kemudian di Abad Pertengahan pada tulisan-tulisan Thomas Aquinas, kita menjumpai pemahaman tentang yang indah itu

1 G. M. A. Grube, "Plato's Theory of Beauty" dalam The Monist, Vol. 37, No. 2 (April, 1927) (Oxford: Oxford University Press, 1927), 269. 
sebagai 'seimbang, teratur, dan proposional'. ${ }^{2}$ lebih lanjut, yang indah itu dapat dijadikan sarana untuk membawa penikmatnya menuju kontemplasi, melepaskan diri dari keterkungkungan subyek, untuk mencapai keindahan yang ada 'di seberang sana'. Selain di dalam pemikiran Plato, yang belakangan ini dapat kita jumpai pula di dalam karya-karya Plotinus dan Augustinus. ${ }^{3}$ Kaum Stoics dan Epicurean memahami yang indah itu sebagai yang dapat menentramkan jiwa, mengingatkan pada logos, keteraturan dan simetri. ${ }^{4}$ Beberapa pemikir, seperti Aristotle dan Aquinas menekankan juga sisi subyektif dari keindahan, yaitu 'pengalaman estetis' ketika si subyek berjumpa dengan obyek estetisnya. Plato memiliki konsep bahwa realita materi yang dapat kita indera secara empirik adalah imitasi (mimesis) dari keindahan sempurna yang hanya ada di alam idea. Dalam sebuah percakapan tentang puisi dan hal-hal yang tidak nyata (Poetry and Unreality), Plato mengangkat sebuah contoh tentang tiga jenis ranjang, yaitu, yang ideal, yang dapat ditiduri, dan yang dilukiskan oleh seorang seniman:

2 Dr. FX. Mudji Sutrisno, S. J. \& Prof. Dr. Christ Verhaak, S. J., Estetika Filsafat Keindahan (Yogyakarta: Kanisius, 1993), 34.

3 Dalam An Essay on the Beautiful (terjemahan Thomas Taylor (1917) - dapat diakses di http://www.gutenberg.org/ebooks/29510) Plotinus menulis, “... It is now time, leaving every object of sense far behind, to contemplate, by a certain ascent, a beauty of a much higher order; a beauty not visible to the corporeal eye, but alone manifest to the brighter eye of the soul, independent of all corporeal aid." Mengenai hal ini Augustinus menulis, "We cannot help loving what is beautiful" dalam On Music (387-391), VI, 13.

4 Dalam The Golden Sayings of Epictetus Nr. XIII (terjemahan Hastings Crossley (2006) dapat diakses di http://www.gutenberg.org/files/871/871-h/871-h.htm), Epictetus mengatakan, "But God hath introduced Man to be a spectator of Himself and of His works; and not a spectator only, but also an interpreter of them. Wherefore it is a shame for man to begin and to leave off where the brutes do. Rather he should begin there, and leave off where Nature leaves off in us: and that is at contemplation, and understanding, and a manner of life that is in harmony with herself. See then that ye die not without being spectators of these things." 
"He would not, said he, as it should seem to those who are acquainted with such discussions. We must not then be surprised if this likewise should seem somewhat obscure compared with the truth. Certainly not. Are you willing then, said I, that as regards these very things we inquire concerning the real nature of their imitator? If you please, he replied. Are there not then these three sorts of beds: one existing in nature, and which we may say, I suppose, God made, or who else? No one, I think. And another which the joiner makes? Yes, said he. And a third which the painter makes: is it not so? Granted. Now the painter, the bed-maker, God, these three are the masters of three species of beds? They are three indeed. But God, whether it were that he was unwilling, or whether there was some necessity that he should only make one bed in nature, made this one only, which is really a bed; while two or more of such other species have never been produced, nor ever will be produced by God."5

Jika alam semesta beserta segala keindahannya hanyalah tiruan (tak sempurna) dari kesempurnaan alam idea, maka keindahan yang dihasilkan oleh kesenian adalah tiruan (tak sempurna) dari tiruan (tak sempurna) atau mimesis memeseos. Kesenian yang baik (yang indah) adalah kesenian yang dapat mengimitasi keindahan alam dengan semirip mungkin. Dengan kata lain, dalam pandangan Plato tidak ada tempat bagi peran orisinil si seniman sebagai subyek pada karya rupa yang dibuatnya. Barangkali inilah sebabnya kesenian Yunani sangat bersifat naturalistik. ${ }^{6}$ Mereka membuat patung dewa-dewi mereka dengan proporsi anatomi yang mereka anggap sempurna, yaitu sebagaimana mereka lihat di dalam alam - bahkan melampauinya, karena apa yang mata kita lihat adalah juga imitasi dari kenyataan sebenarnya (yang tidak terlihat). Pemikiran ini ada di belakang gaya naturalistik ketika mereka membuat patung yang lebih indah dari

5 Plato, The Repulic, Book X, p. 322 (diakses pada tanggal 12 September 2015 di dalam laman http://www.forgottenbooks.com/readbook_text/The_Republic_1000181025/341). Penekanan dari penulis.

6 Jerome J. Pollitt, "Early Classical Greek Art in a Platonic Universe" dalam Cedric G. Boulter, Greek Art: Archaic Into Classical : a Symposium Held at the University of Cincinnati April 2-3, 1982 (Leiden: Brill, 1985), 99. 
manusia kebanyakan, mereka membuat sosok anatomi manusia ideal. Pandangan seperti ini cukup sukses diterima dalam sepanjang sejarah. Tanpa pengertian seni yang memadai, hampir semua orang 'awam' akan lebih menyukai seni rupa naturalistik ketimbang kubistik (yang lebih mirip corat-coret saja).

Aristotle, murid Plato yang paling brilian, walaupun seperti juga Plato masih menganggap kesenian sebagai imitasi alam, berpendapat bahwa kesenian memiliki nilai fungsional dalam hidup manusia. ${ }^{7}$ Melalui kesenian, khususnya drama-drama tragedi yang dikembangkannya, jiwa manusia dapat disucikan/ dibersihkan (Katharsis) dari kelemahan-kelemahannya. Drama-drama Yunani, menurut Aristotle, memiliki ciri-ciri audiens dibawa melewati alur cerita yang disusun secara logis dan teratur menuju suatu titik akhir yang mengejutkan, dimana segala sesuatunya menjadi jelas, segala misteri terpecahkan dan ada hubungan antara semua adegan-adegan terpisah yang mulanya tak terlihat berkaitan. Saat akhir drama tercapai para penonton seolah-olah mengalami suatu pembersihan jiwa (katarsis). Mengomentari genre tragedi di dalam drama-drama Yunani, Aristotle menggarisbawahi fungsi katarsisnya

A tragedy, then, is the imitation of an action that is serious and also, having magnitude, complete in itself; in language with pleasurable accessories, each kind brought in separately in the parts of the work; in a dramatic, not in narrative form; with incidents arousing pity and fear, wherewith to accomplish its catharsis of such emotions. ${ }^{8}$

7 Seneca mengatakan mengenai Aristotle bahwa baginya tujuan seni adalah untuk menyingkapkan apa yang terdapat di dalam realitas. The aim of art is to represent not the outward appearance of things, but their inward significance.

8 Aristotle, Poetics (London: Penguin Classics, 1997) 1449b, 25. 
E.R. Dodds berpendapat bahwa hal ini secara lebih spesifik dapat dilihat di dalam analisa Aristotle mengenai karakter Oedipus.

... what fascinates us is the spectacle of a man freely choosing, from the highest motives a series of actions which lead to his own ruin. Oedipus might have left the plague to take its course; but pity for the sufferings of his people compelled him to consult Delphi. When Apollo's word came back, he might still have left the murder of Laius uninvestigated; but piety and justice required him to act. He need not have forced the truth from the reluctant Theban herdsman; but because he cannot rest content with a lie, he must tear away the last veil from the illusion in which he has lived so long. Teiresias, Jocasta, the herdsman, each in turn tries to stop him, but in vain; he must read the last riddle, the riddle of his own life. The immediate cause of Oedipus' ruin is not "fate or "the gods" - no oracle said that he must discover the truth-and still less does it lie in his own weakness; what causes his ruin is his own strength and courage, his loyalty to Thebes, and his loyalty to the truth.... But what is the alternative? If Oedipus is the innocent victim of a doom which he cannot avoid, does this not reduce him to a mere puppet? Is not the whole play a 'tragedy of destiny' which denies human freedom??

Jadi, berbeda dengan Plato, Aristotle mulai mengembangkan konsep keindahan yang melibatkan pengalaman si subyek.Ini adalah kontribusi penting yang diberikannya pada perkembangan sejarah estetika Yunani klasik. Munculnya peranan si Subyek ini pada Abad Pertengahan nanti akan dikembangkan lebih jauh lagi oleh Thomas Aquinas.

Thomas Aquinas, merangkum semua gagasan tentang keindahan yang dipelajarinya dari sumber-sumber Yunani klasik, khususnya ide tentang teori musik dan proporsi matematis di dalam ontologi keindahan. ${ }^{10}$ Kita dapat menjumpainya di dalam Summa Theologia, karya besar Thomas

9 E.R. Dodds, "On Misunderstanding the Oedipus Rex,"dalam Greece and Rome, Vol. 13 Nr. 1 (Cambridge: Cambridge University Press, 1966), 42-43.

10 Umberto Eco, The Aesthetics of Thomas Aquinas (Cambridge: Harvard University Press, 1988), $81,132,134$. 
Aquinas yang menjadi acuan para teolog Katolik selama berabad-abad. Bukan hanya mengekor kepada pemikiran Yunani kuno, Aquinas juga mengembangkannya. Sumbangan orisinal Aquinas dapat dikatakan paling terlihat pada peranannya mengarahkan perhatian kesenian dan pengalaman keindahan pada peranan rasa si subyek dalam proses penciptaan karya seni. Aquinas mendefinisikan keindahan sebagai ‘apa yang menyenangkan ketika dilihat. ${ }^{\prime 11}$ Walaupun keindahan didalam konsep Thomas Aquinas masihlah rasionalistik, tetapi kini ia melibatkan afeksi si subyek - tidak melulu berbicara mengenai kualitas dari obyeknya. Lebih lanjut, Thomas Aquinas menjelaskan bahwa keindahan haruslah mencakup tiga kualitas: integritas, proporsi yang benar, dan kejernihan ('clarity' atau 'brightness').

For beauty includes three conditions, 'integrity' or 'perfection,' since those things which are impaired are by the very fact ugly; due 'proportion' or 'harmony'; and lastly, 'brightness' or 'clarity,' whence things are called beautiful which have a bright color. ${ }^{12}$

Keindahan itu bagi Aquinas dialami pertama-tama melalui intelek si subyek. Keindahan dialami jika si subyek mengarahkan dirinya lewat kontemplasi atau lewat pengetahuan empiris. Itulah sebabnya Aquinas berpendapat bahwa indera-indera yang paling berhubungan dengan pengetahuan-lah yang paling berperan dalam pengalaman keindahan. Maka indera yang paling penting dalam estetika adalah mata dan telinga, dan seni yang paling penting adalah yang melibatkan kedua indera ini, seperti seni rupa, musik, puisi, atau opera. Kita, kilah Aquinas, tidak berbicara tentang

\footnotetext{
11 "... beauty is that which gives pleasure when seen" Thomas Aquinas, Summa Theologia, Book I, part 1, Q 39. art. 8, juga Book II, part 1 Q 27. art. 1. reply to obj. 3.
}

12 Aquinas, Summa Theologia, Book I, part 1, Q 39. art. 8. 
'rasa atau bau-bauan yang indah' - melainkan pemandangan atau suara yang indah.

The beautiful is the same as the good, and they differ in aspect only. For since good is what all seek, the notion of good is that which calms the desire; while the notion of the beautiful is that which calms the desire, by being seen or known. Consequently those senses chiefly regard the beautiful, which are the most cognitive, viz. sight and hearing, as ministering to reason; for we speak of beautiful sights and beautiful sounds. But in reference to the other objects of the other senses, we do not use the expression "beautiful," for we do not speak of beautiful tastes, and beautiful odors. Thus it is evident that beauty adds to goodness a relation to the cognitive faculty: so that "good" means that which simply pleases the appetite; while the "beautiful" is something pleasant to apprehend. ${ }^{13}$

Pandangan Aquinas ini menjadi salah satu titik balik dalam perkembangan kesenian. Jika sebelumnya, orang kurang menekankan peranan subyek dalam penciptaan seni, kini peran subyek mulai diperhatikan. Misalkan saja, dalam seni lukis Byzantium wajah-wajah manusia dan malaikat dilukiskan seragam dan tanpa ekspresi, dalam perkembangan di Abad Pertengahan setelah Aquinas wajah manusia dalam karya seni mulai dilukis secara personal dan diberi ekspresi yang diambil dari model hidup yang berpose di depan si pelukis. ${ }^{14}$

\section{Dari Leonardo da Vinci sampai Rudolf Schwarzkogler}

Setelah abad pertengahan, secara umum ada kecenderungan perkembangan kesenian dan konsep keindahan dari yang konkret (seperti Monalisa) menuju kesenian yang semakin abstrak (misalnya Who's Afraid of

13 Aquinas, Summa Theologia, Book II, part 1 Q 27. art. 1. reply to obj. 3.

14 Sutrisno \& Verhaak, Estetika, 40. 
Red, Yellow and Blue III). ${ }^{15}$ Hal ini sesuai hierarki kesenian menurut Hegel dan Schopenhauer, yang bergerak dari ekspresi yang konkret ke tingkat abstraksi yang lebih tinggi. ${ }^{16}$ Makin tinggi suatu kesenian dalam hierarki itu, makin sedikit 'kandungan material-nya'. Sekarang kita akan menelusuri perkembangan seni Modern dari awalnya, yaitu masa Renaissance.

Pada masa awal Renaissance, Marsilio Ficino, ${ }^{17}$ seorang anggota Akademi yang mempelajari filsafat Plato di Italia, mengajukan pandangannya bahwa penciptaan karya seni harus diawali dengan "konsentrasi yang mengarah pada inti batin" si seniman, ini mirip dengan metode rekoleksi Plato ditambah dengan dualisme mirip rasionalisme, yang belum muncul saat itu. Penyelidikan mengenai asas-asas keindahan yang harus dipenuhi suatu karya seni baik pada proses maupun produknya akhirnya melahirkan pandangan-pandangan seperti Alberti, Michaelangelo, Raphael, da Vinci dan Duerer. Leonardo da Vinci melakukan studi mengenai hukum-hukum perspektif dan anatomi manusia, ia berpendapat hukum-hukum ini harus dikuasai sepenuhnya agar si seniman dapat menghasilkan karya seni tingkat tinggi. Mereka mempunyai pandangan, makin taat seorang seniman kepada hukum-hukum ini, semakin bebas dia menghasilkan karyanya. Para perupa dari masa ini menghasilkan karya seni yang mengagumkan, mereka membuatnya dengan penuh ketelitian, hingga

\footnotetext{
15 Sebuah karya abstrak Barnett Newman seharga US\$ 3,1 Juta, di Amsterdam's Stedelijk Museum.Lukisan modern ini hanyalah sebidang kanvas raksasa yang dicat merah terang dengan garis batas biru tipis pada pinggiran sebelah kirinya.

16 G. W. F. Hegel, Hegel's Aesthetics: Lectures on Fine Art Vol. 1. teks dalam public domain dapat diakses di www.timothyquigley.net/vcs/hegel-aesth8.pdf.

17 Sutrisno \& Verhaak, Estetika, 43.
} 
hal-hal yang paling detil sekalipun. Ekspresi subyektif diungkapkan melalui karya-karya seni Renaissance yang sangat realistis, namun bukan sekedar tiruan dari alam.

Masa Renaissance diikuti oleh kebangkitan rasionalisme-empirisme pada kebudayaan Eropa. Pada periode Enlightenment kesenian cenderung menjadi kering terhadap ekspresi emosional si seniman, karya-karya yang indah itu nyaris matematis murni. ${ }^{18}$ Hal ini memicu pemberontakan terhadap tradisi rasionalisme, pendulum cenderung berayun ke ekstrim lain yang sangat menekankan subyektivitas emosi. Albert Camus pernah mengatakan bahwa pemberontakan adalah kreatif. Menjadi kreatif berarti memberontak terhadap belenggu status quo dengan mencari alternatif. Pemberontakan ini terutama melanda konsep keindahan yang dibangun oleh Aquinas, da Vinci, Michaelangelo dan rekan-rekannya. Yang indah itu tidak harus proporsional dan natural. “Tidak ada seorangpun seniman yang dapat menerima kenyataan," kata Nietzsche. ${ }^{19}$ Sikap mengambil jarak antara karya seni terhadap realitas alamiah juga dapat kita jumpai pada Vincent van Gogh. Ia berpendapat bahwa "Dunia adalah hasil lukisan Tuhan yang gagal." ${ }^{20}$ Pada periode ini banyak seniman melihat dirinya sebagai seseorang yang berkreasi melalui bidang seni, menggunakan hukum logika tersendiri

18 Pergerakan ke arah ini dapat kita lihat misalnya dalam pergantian gaya dekorasi pada era Baroque kepada Rococo, lalu dilanjutkan kepada Neo-Classical. Dekorasinya semakin rasional, elegan, dan sederhana.Hilang sudah extravagance dan embel-embel serba berkelebihan dari zaman Baroque.Untuk rujukan lebih lanjut dapat dibaca di Michael Levey Painting in Eighteenth-Century Venice (Ithaca: Cornell University Press, 1980).

19 Albert Camus, dll, Seni dan Pemberontakan(Yogyakarta: Bentang Budaya, 1998), 1.

20 Ibid., xv. 
yang berbeda dengan logika bidang-bidang yang lain. ${ }^{21}$ Pandangan yang berkembang di akhir abad ke-19 ini telah menggeser fokus keindahan secara radikal. Orang tidak lagi mengejar proporsi dan perspektif yang 'benar' dalam menghasilkan karya (seperti yang kita dapati pada periode Klasik dan Medieval), sebaliknya si seniman diundang untuk berani menabrak patokan-patokan yang sebelumnya dianggap tabu demi mengekspresikan sebebas mungkin impresi keindahan yang ada dalam diri mereka. Seni adalah ekspresi dari impresi, demikian kata mereka yang akhirnya melahirkan aliran impresionisme dan ekspresionisme..$^{22}$

Dalam abad ke-20 pandangan ini berkembang lebih lanjut dan melahirkan gerakan Simbolisme/ Jugendstil, Fauvisme/ Surrealisme, Kubisme dan seni Abstrak. Tema-tema yang mendasari gerakan ini adalah pembebasan ekspresi keindahan dari belenggu penampakan empiris, bentuk, rasionalisme dan norma-norma yang berlaku umum. Jika ekspresionisme masih berangkat dari pengamatan, Simbolisme menganggap hasil karya seni hanya sebagai 'alasan'/ simbol untuk menggambarkan inti ilham sang seniman. Karena itu jelas karya seni tidak harus 'mirip dengan aslinya' dengan mematuhi hukum-hukum perspektif dan proporsi. Hal ini dilanjutkan oleh gerakan Fauvisme yang dengan sengaja mendistorsi perspektif warna. ${ }^{23}$ Karena pengaruh psikologi Freud, orang mulai memperhatikan dan mengeksplorasi dunia sub-concious yang dianggap

\footnotetext{
21 Ibid., $x v$.

22 Robert L. Herbert, Impressionism: Art, Leisure and Parisian Society (Connecticut, New Haven: Yale University Press, 1991).

23 William H. Gerdts, The Color of Modernism: The American Fauves (New York: Hollis Taggart Galleries, 1997), 160.
} 
dapat membebaskan manusia dari belenggu rasionalisme. Teknik semacam ini dipakai oleh para perupa seperti Ensor, Schwitters, Tanguy, dan Dali untuk melahirkan aliran Surealisme yang mengeksploitasi keindahan dari dunia sub-concious. ${ }^{24}$ Tema pembebasan ini juga berkembang untuk mengungkapkan impresi lewat pencarian bentuk-bentuk dasar realitas. Ini melahirkan gerakan Kubisme yang dipelopori oleh Picasso, Braque, dan Cezanne. Mereka mewujudkannya dalam lukisan yang memakai bentukbentuk yang nyaris geometris untuk menggambarkan manusia, dan warnawarna yang dipakai adalah warna-warna dasar yang saling berdampingan. Berbagai sudut perspektif dilukiskan sekaligus. Ini melahirkan lukisan yang berkesan 'jelek' seperti corat-coret yang kekanak-kanakan. Usaha untuk melepaskan diri dari keterbatasan ekspresi ini dilakukan secara ekstrim oleh aliran Abstrak. Mereka mencoba untuk melahirkan karya seni yang tidak berbentuk, tanpa obyek luar, absolut, dan non-representatif, walaupun karya-karya mereka tetap saja tak dapat melepaskan diri dari bentuk. Walaupun sudah berusaha untuk melepaskan diri dari realitas luar, lukisanlukisan abstrak masih mengingatkan kita pada bentuk-bentuk yang paling primitif. Dalam musik ini diwakili oleh perkembangan musik-musik atonal dari Schoenberg.

Ekses negatif dari kecenderungan pemberontakan ini adalah mereka melahirkan pemberontakan demi pemberontakan itu sendiri. Ini menjadi nyata dalam gerakan Dadaisme dan Neo-Dadaisme yang lahir pada abad ke20. Mereka cenderung bersikap nihilistik, dan seringkali malah destruktif. Hal ini diperparah oleh sikap masyarakat yang cenderung semakin permisif,

24 Andre Breton, Conversations: The Autobiography of Surrealism (Paris: Gallimard, 1952). 
toleran dan hampir-hampir dapat menerima penyimpangan apapun juga. Seniman Neo-dadais menjadi menderita karena tak ada lagi yang dapat diprotes. Tidak ada lagi pelanggaran norma yang dianggap serius, maka mereka mulai mengarahkan kesenian mereka pada tubuh mereka sendiri. Kesenian berkembang ke arah masokisme yang sadistis. Barbara Rose menulis:

Gambaran-gambaran masokisme, mutilasi diri, dan perusakan diri bertimbun, selagi seniman yang dirampas kesempatannya untuk protes, menjadikan dirinya korban. Perasaan impotensi sang seniman itu sebagian berasal dari perasaannya bahwa masyarakat tidak lagi memberinya kemungkinan untuk bertindak dengan bertanggung jawab. ${ }^{25}$

Contoh yang paling ekstrim adalah seniman instalasi Jerman, Rudolf Schwarzkogler yang memamerkan serangkaian foto-foto dokumentasi halhal absurd yang tak saling berhubungan. ${ }^{26}$ Praktek-praktek seperti ini sudah begitu marak sehingga sudah merupakan repetisi yang secara tragis membosankan.

Hingga kini usaha untuk menikmati dan menciptakan keindahan sudah melahirkan hal-hal yang buruk seperti ini. Kemana lagi perjalanan sejarah keindahan ini akan membawa kita selanjutnya? Apakah kekristenan dapat menawarkan alternatif yang segar dan menghidupkan bagi

25 Sebuah artikel yang ditulis Barbara Rose dalam: Camus, Seni dan Pemberontakan, 115-116.

26 Robert Hughes melaporkan di dalam majalah Time edisi 18 Desember 1972, "The Decline and Fall of the Avant-Garde," bahwa Rudolf Schwarzkogler telah mengebiri dirinya sampai mati kehabisan darah dan mendokumentasikannya dalam sebuah karya berjudul Documentia Nr. 5 Aktion \#2. Tetapi ini adalah berita yang salah.Si seniman sesungguhnya mati karena kecelakaan bertahun-tahun kemudian. Risalah mengenai hal ini dapat dibaca di Susan Jarosi, "The Image of the Artist in Performance Art: The Case of Rudolf Schwarzkogler" dalam Sztuka i Dokumentacja, nr 8 (2013), 65. 
perkembangan dunia seni? Berikut ini kita akan meninjau salah satu sumber dari kekristenan, yaitu Alkitab. Visi seperti apakah yang dibentangkan Alkitab mengenai hal ini?

\section{Survey Alkitab}

Mengenai 'keindahan' ada berbagai rujukan yang dapat kita pertimbangkan, misalnya: Daud dalam Mazmurnya menyebut 'Taurat', 'Titah Tuhan', dan 'Takut akan Tuhan' sebagai ‘lebih indah dari emas' (mis. Mzm. 19:10-11). Para penulis PL yang lain juga memakai kata yang sama untuk menyebutkan keagungan, perasaan gentar dan takjub akan kehadiran Tuhan (Mzm. 96: 9, Yes. 8: 13). Selain itu, di dalam urusan yang lebih banal istilah 'keindahan' juga dikaitkan dengan kecantikan fisik seorang wanita (mis. Kej. 29: 17, Kid. 1: 15, 4:1, 4: 7). Ada 42 dari sekitar 100 ayat yang ditelusuri memakai kata pencarian "Beauty", "Beautiful", dan "Artistic" merujuk pada kecantikan seorang wanita. Kecantikan feminin seringkali digambarkan secara analogis terhadap keindahan alam. Hal ini, misalnya, sangat kerap kita jumpai dalam puisi-puisi Kidung Agung. Selain merujuk kepada Tuhan dan wanita, keindahan di dalam Alkitab juga sering dikaitkan dengan keindahan alam liar. Beberapa penulis Alkitab menyebutkan perasaan keindahan yang muncul saat memandang kecantikan seekor rusa (Kej. 49:21), Tanah Perjanjian (Yer. 3:19), atau Rasi Bintang (Ayb. 38:31). Bahkan perasaan puas dalam diri Tuhan saat melihat ciptaan-Nya mula-mula (mis. Kej. 1:10, 12). Di dalam daftar ini kita juga bisa tambahkan rujukan kepada keindahan seni buatan manusia. Termasuk 
dalam bagian ini adalah ungkapan kekaguman pada kemegahan arsitektur ${ }^{27}$ bangsa-bangsa non-Israel (mis. Yeh. 27:4), fashion (Kej. 41:42), musik (Yeh. 33:32), dan peralatan ibadah dalam Tabernacle. Tetapi rujukan kepada keindahan yang abstrak hanya muncul sekali dalam PB, yaitu ketika Yesus memuji tindakan wanita yang mengurapi kepalanya dengan minyak Narwastu. Yesus menyebut sebuah tindakan, yang tentu saja formless, disebut dengan istilah "beautiful".

\section{Visi Estetika Ibrani}

Visi tentang keindahan dan kesenian yang dihasilkan orang-orang Ibrani sangat berbeda dengan kesenian-kesenian budaya lain yang bersifat antroposentris. $^{28}$ Ekspresi kesenian orang Ibrani dimulai dengan pengalaman keindahan dalam menikmati Tuhan. Rabbi Jonathan Sacks berpendapat di sinilah perbedaan antara sikap orang-orang Yunani kuno dan umat Ibrani terhadap keindahan dan kekudusan:

At the risk of oversimplification, one could state the difference between ancient Israel and ancient Greece thus: that where the Greeks believed in the holiness of beauty, Jews believed in hadrat kodesh, the beauty of holiness. ${ }^{29}$

Theolog Puritan, Jonathan Edwards juga menekankan kekudusan sebagai sumber dari keindahan Tuhan, "The beauty of the divine nature does

\footnotetext{
27 Sayang sekali, bangsa Ibrani tidak mengembangkan seni arsitektur. Salomo sampai harus mengimpor tenaga ahli dari Raja Hiram untuk membangun bait suci (2 Taw. 2:7).

28 Rabbi Jonathan Sacks mengatakan, "Judaism does not believe in art for art's sake, but in art in the service of God, giving back as a votive offering to God a little of the beauty He has made in this created world."

29 Dapat dibaca di dalam laman http://www.rabbisacks.org/covenant-conversation-5772tetzaveh-the-aesthetic-in-judaism/ diakses pada tanggal 14 September 2015.
} 
primarily consist in God's holiness...the beauty of His moral attributes." ${ }^{30}$ Lebih lanjut, G. von Rad berpendapat bahwa puncak pengalaman keindahan orang Ibrani adalah di dalam lingkup religius. ${ }^{31}$ Pengalaman keindahan mereka bersumber dari realisasi kekaguman, kegentaran, dan rasa cinta yang mendalam pada YHWH. Perasaan keindahan itu terjadi ketika mereka menyadari kehadiran YHWH, kebijaksanaan-Nya dan pekerjaan-pekerjaanNya yang ajaib. Edmund Clowney menulis, "The wonder of aesthetic experience echoes the awe found in the presence of God, who is not only One but Three, not only Judge but Saviour, not Only Lord but Saviour."32

Transendensi Allah, misteri ilahi yang menggentarkan inilah yang menjadi inti dan sumber pengalaman dan pengungkapan keindahan orang Ibrani. Lebih lanjut, Von Rad menyimpulkan empat ciri konsep keindahan Ibrani, yaitu: 1) Keindahan itu tidak pernah menjadi sesuatu yang absolut, yang ada pada dirinya sendiri. Keindahan selalu berupa sesuatu yang tak henti-hentinya dilimpahkan ke dalam dunia oleh Tuhan. 2) Keindahan berkaitan langsung dengan iman. 3) Proses menikmati keindahan Tuhan ini terutama berbentuk Mazmur dan terutama Nubuatan (prophecy). Prophecy is perception in faith, and faith perceived. 4) Israel bukan hanya melihat keindahan di secara positif, tetapi juga secara negatif. Mereka memersepsi kehadiran Allah sebagai keindahan, tetapi juga menikmati keagungan Ilahi dalam ketidak-hadiran Allah dan sisi misterius YHWH. Bukan hanya pengetahuan

30 Edmund P. Clowney, "Living Art: Christian Experience and the Arts," dalam God and Culture, D. A. Carson \& John D. Woodbridge (Michigan: Eerdmans, 1993).

31 Gerhard Von Rad, Old Testament Theology Vol.1 (London: SCM Press, 1975), 366.

32 Edmund P. Clowney, "Living Art: Christian Experience and The Arts", dalam God and Culture, D. A. Carson \& John D. Woodbridge (Michigan: Eerdmans, 1993), 250. 
orang Israel tentang Allah yang menyebabkannya mengalami keindahan, tetapi juga hal-hal misterius yang tak diketahuinya tentang Allah, yang membuatnya tunduk dengan gentar pada kedahsyatan transendensi YHWH.

Dominasi Teosentrisme dalam budaya Ibrani membuat semua produk kesenian Ibrani juga menjadi Teosentris. Menikmati Tuhan dalam segala kelimpahan dan kemuliaan-Nya adalah cita-cita tertinggi, keinginan terbesar dari setiap orang Ibrani yang takut akan Tuhan. Kesenian mereka adalah wujud ekspresi pengalaman keindahan yang dialami bersama YHWH. Ekstase inilah sumber ekspresi seni Ibrani. Hal ini paling banyak diekspresikan lewat media bahasa, sastra, dan musik.

\section{Media Kesenian Ibrani}

Bangsa Ibrani tidak banyak meninggalkan artefak seni rupa yang tinggi. Tidak arsitektur atau patung-patung yang impresif seperti yang dapat dijumpai pada reruntuhan kota-kota peninggalan bangsa Sumeria, Mesir, Yunani atau Romawi. ${ }^{33}$ Tidak ada artefak-artefak indah seperti yang dapat ditemukan di piramida-piramida Mesir atau di istana kaisar-kaisar

\footnotetext{
33 Rabbi Jonathan Sacks mengatakan demikian: "The great empires - Mesopotamia, Egypt, Assyria, Babylon, Greece and Rome - built monumental palaces and temples. The royal courts were marked by magnificent robes, cloaks, crowns and regalia, each rank with its own uniform and finery. Judaism by contrast often seems almost puritanical in its avoidance of pomp and display. Worshipping the invisible God, Judaism tended to devalue the visual in favour of the oral and aural: words heard rather than appearances seen." Pembahasan selanjutnya dapat dibaca di dalam laman http://www.rabbisacks.org/covenant-conversation-5772-tetzaveh-the-aesthetic-in-judaism/ diakses pada tanggal 14 September 2015.
} 
Cina. Ada dua alasan mengapa hal ini terjadi. Pertama adalah karena selama berabad-abad bangsa Ibrani salah menafsirkan hukum kedua dari Taurat, ${ }^{34}$

Jangan membuat bagimu patung yang menyerupai apapun yang ada di langit di atas, atau yang ada di bumi di bawah, atau yang ada di dalam air di bawah bumi. Jangan sujud menyembah kepadanya atau beribadah kepadanya, sebab Aku, TUHAN, Allahmu adalah Allah yang cemburu, yang membalaskan kesalahan bapa kepada anak-anaknya, kepada keturunan ketiga, dan keempat dari orang-orang yang membenci Aku, tetapi Aku menunjukkan kasih setia kepada beribu-ribu orang, yaitu mereka yang mengasihi Aku dan yang berpegang pada perintah-perintah- $\mathrm{Ku} .{ }^{35}$

Mereka menafsirkan hukum ini sebagai larangan bagi mereka untuk membuat patung atau rupa apapun yang menyerupai bentuk ciptaan Tuhan. Padahal yang Tuhan maksudkan adalah mereka tidak boleh membuat patung atau wujud apapun untuk disembah. Hal ini dijelaskan pada kalimat "Aku...adalah Allah yang cemburu..."36 Lagi pula Allah sendiri di waktu-waktu kemudian memerintahkan Musa untuk membuat tutup perdamaian pada Tabut Perjanjian yang dilengkapi dengan sepasang patung Kerub yang terbuat dari emas. Ini menunjukkan bahwa YHWH tidak pernah melarang orang Israel untuk membuat patung, asalkan patung itu tidak dijadikan berhala. Salah tafsir ini sudah terjadi secara berabad-abad dan telah menjauhkan seni rupa tinggi dari kebudayaan Israel (kecuali pada

\footnotetext{
34 Joseph Gutmann, "The "Second Commandment" and the Image in Judaism" dalam Hebrew Union College Annual Vol. 32 (Hebrew Union College, Jewish Institute of Religion, 1961), 161174.

35 Keluaran 20: 4-6

36 Penyembahan berhala di dalam PL sering digambarkan sebagai perzinahan, Tuhan menyebutkan reaksi-Nya atas penyembahan berhala dengan istilah "cemburu" - istilah yang dipakai untuk menunjukkan kemarahan dan sakit hati seorang suami yang istrinya menyeleweng (mis. Hosea 2: 5-13).
} 
masa Bezaleel dan Aholiab, Tuhan mengurapi mereka khusus untuk membuat artefak-artefak religius bagi keperluan ibadah di Tabernakel).

Rabbi Jonathan Sacks berpendapat bahwa untuk urusan pembikinan patung-patung ada perkecualian khusus pada konteks fasilitas ibadah kepada YHWH. Berikut ini adalah argumentasi Biblika yang diberikan Sacks. Kata 'kemuliaan' (kabod) di dalam PL muncul 16 kali, 14 (2x7) diantaranya merujuk kepada kemuliaan TUHAN, hanya dua kali kata itu dikenakan kepada manusia, yaitu dalam peraturan Musa mengenai pakaian imam. ${ }^{37}$ Mengutip Moses Maimonides, Sacks menjelaskan alasannya: karena kelemahan orang banyak yang memang tidak mampu melihat nilai hakiki manusia, tetapi lebih memandang atribut superficial, yaitu pakaian yang dikenakan pemimpinnya:

In order to exalt the Temple, those who ministered there received great honour, and the priests and Levites were therefore distinguished from the rest. It was commanded that the priest should be clothed properly with the most splendid and fine clothes, "holy garments for glory and for beauty" ... for the multitude does not estimate man by his true form but by ... the beauty of his garments, and the Temple was to be held in great reverence by all. . $^{38}$

Dengan kata lain, di sini kesenian memiliki peranan didaktis menuntun umat Allah dari kelemahan dan kebodohan ke dalam keadaan yang lebih baik, melalui dekorasi di rumah Allah. Contoh yang lain dapat kita lihat di dalam perintah Tuhan mengenai dekorasi pada pakaian umat Israel,

\footnotetext{
37 Keluaran 28: 4 dan 28: 40.

38 Moses Maimonides, Guide for the Perplexed, III:45.
} 
Berbicaralah kepada umat Israel dan katakanlah kepada mereka, bahwa mereka harus membuat jumbai-jumbai pada punca baju mereka, turun temurun, dan dalam jumbai-jumbai punca itu haruslah dibubuhi benang ungu kebiru-biruan. Maka jumbai itu akan mengingatkan kamu, apabila kamu melihatnya, kepada segala perintah TUHAN, sehingga kamu melakukannya, dan tidak lagi menuruti mata hatimu atau matamu sendiri, seperti biasa kamu perbuat dalam ketidaksetiaanmu kepada TUHAN. ... dan menjadi kudus bagi Allahmu. ${ }^{39}$

Alasan kedua adalah karena bahasa/ sastra yaitu media yang bersifat audible memiliki keunggulan dalam mengakomodasi ekspresi keindahan bangsa Ibrani, sebagai bangsa yang mengikat janji dengan Allah YHWH, yang tidak terdapat pada bangsa-bangsa lain. Walau kurang menonjol dalam bidang seni rupa, bangsa Ibrani sangat unggul dalam bidang sastra. Alkitab PL adalah karya sastra yang tak ada bandingannya, bahkan sampai saat ini. Bangsa Ibrani menuangkan ekspresi keindahannya dalam mediamedia audible/ bahasa seperti musik (Kel. 15, 1 Sam. 18:6-7, 10), puisi (Ayub, Mazmur, Kidung Agung, kitab nabi-nabi), dan narasi (Sebagian besar PL terdiri dari narasi kelas tinggi). Kelihatannya media-media seperti ini lebih mampu untuk mengakomodasi ekspresi keindahan personal secara akurat. Ini berkaitan langsung dengan sifat-sifat alamiah media audio dan visual.

Pendengaran adalah salah satu pengalaman yang paling pribadi (private) dalam hidup kita. ${ }^{40}$ Indera pendengaran kita bersifat pasif, tak seperti penglihatan, kita tidak dapat memilih secara aktif hal-hal yang ingin kita dengar. Karena tak memiliki 'kelopak telinga' kita tak dapat tidak, pasti mendengar apa-apa yang ada di sekeliling kita, kita hanya dapat memilah-

\footnotetext{
39 Bilangan 15: 38-40.

40 Charles Sherlock, The Doctrine of Humanity (Illinois: IVP, 1996), 223.
} 
milah informasi terdengar ini di dalam. Suara juga tak dapat diraba dan pada jaman pra-modern tak dapat disimpan. Pengalaman bunyi bersifat unik, personal, dan eksistensial, tidak pernah ada pengalaman bunyi yang dapat diulang lagi sekehendak pendengar. Hal ini membuat pengalaman bunyi lebih aman terhadap godaan untuk disembah (melalui repetisi rangsang yang dilakukan atas pilihan pendengar). ${ }^{41}$ Tuhan Yesus berbicara tentang "mencongkel biji mata" untuk meminimalkan godaan dan tak pernah berbicara tentang "menulikan telinga" untuk menghindari pencobaan. Rasul Paulus berbicara tentang "Iman yang timbul dari pendengaran."

Media audio juga dapat mengekspresikan perasaan dan pikiran dengan lebih akurat (icon-icon visual bersifat lebih ambigu, memberikan banyak ruang bagi penafsiran yang beragam). Dalam bidang bahasa, hal ini dapat dilihat dalam perkembangan bahasa purba yang mengarah pada simbol-simbol yang lebih literal. Sejarah mencatat perkembangan bahasa dari icon-icon visual hieroglif Mesir menuju abjad-abjad semitik yang lebih literal. Selain itu, media bahasa memiliki daya penetrasi yang lebih kuat pada peradaban purba, karena ada media penyimpananan (bahasa, tulisan, papirus) media audio dapat melintasi waktu. Semua hal ini membuat peran media bahasa/ audio sangat besar dalam era Reformasi Gereja. Protestanisme di awal kemunculannya sangat alergi dengan icon, dan sangat menekankan penggunaan media bahasa. Tuhan kita mewahyukan

\footnotetext{
41 Repetisi rangsang atas pilihan pelihat dilakukan misalnya dengan memfokuskan perhatian pada suatu obyek visual, seperti patung (berhala).Pada jaman pra-modern, suara tak dapat direkam dan dimainkan kembali, sehingga kita tak dapat terus-menerus mengulang suara yang identik. Musik yang dimainkan berulang-ulang pun tidak pernah terdengar persis sama, sehingga memang media audio relatif lebih 'aman' dari potensi menjadi media penyembahan berhala.
} 
diri-Nya dalam media bahasa literal, Ia memperdengarkan suara-Nya pada bangsa Israel, Nabi-nabi dan Rasul tetapi tidak pernah menampakkan wujud-Nya.

\section{Seni Sebagai Penanda yang Merujuk Kepada yang Lain}

Inti dari keindahan di dalam pemahaman Kristiani dan Ibrani ada dalam kekudusan Tuhan sendiri, sehingga konsep keindahan yang benar hanya dapat diketahui dengan mengenal Allah dan kekudusan-Nya. Allah telah menciptakan seluruh realita tempat kita hidup dan mengalami segala kelimpahan-Nya, termasuk pengalaman keindahan. Karena itu, wajar saja jika kita mencoba untuk meneladani prinsip-prinsip moral dan etika Allah dalam menciptakan alam semesta. Ini dapat kita lakukan karena Allah menciptakan kita sebagai imago Dei yang mewakili-Nya dalam dunia ciptaan ini. Tentu saja kita juga harus mengingat perbedaan kualitatif yang ada antara kita dan Allah sehingga kita tidak membuat asumsi yang salah dalam menerapkan prinsip-prinsip menciptakan karya seni. Pertama-tama kita harus ingat bahwa Allah menciptakan dari ketiadaan (creatio ex nihilo), sedangkan kita menciptakan dari sesuatu yang ada sebelumnya. Bahanbahan baku penciptaan ini dapat berupa bahan-bahan fisik, seperti material untuk membuat lukisan, patung, atau arsitektur, atau berupa software yaitu ide-ide yang telah ada terlebih dahulu dan segala kemampuan mencipta (atau mengkomposisi) yang Tuhan berikan pada kita. Beethoven tidak menciptakan musiknya dari ketiadaan; ia menciptakan Symphony No. 9 nya dengan sistem tangga nada dan hukum-hukum harmoni yang telah diciptakan terlebih dahulu oleh orang-orang sebelumnya. Setiap kita selalu 
standing on a giant's shoulder. Selain itu, seorang Beethoven dapat mencipta karena Tuhan telah menciptakan alam semesta dengan segala hukumhukum fisika dan fisiologis yang memungkinkan manusia mengalami keindahan dalam harmoni sebuah komposisi. Mengenai hal ini, Harold M. Best mengajukan sebuah hipotesis yang diturunkan dari asumsi bahwa Tuhan ingin kita meneladani-Nya juga dalam jejak penciptaan-Nya, tentu saja sebatas kemampuan seorang manusia. ${ }^{42}$ Berikut ini adalah proposisiproposisi yang diajukan Best:

1. Tuhan adalah I AM THAT I AM yang tidak menciptakan untuk membuktikan diri-Nya. Ia self-sufficient sehingga Ia bertindak dalam kebebasan dan bijaksana pilihan-Nya sendiri. Kita sebagai ciptaan Tuhan seharusnya juga tidak menciptakan untuk membuktikan diri karena kita sesungguhnya sudah memiliki jati diri yang stabil dan tak tergantung pada sesuatu yang tak tetap seperti pencapaian dalam seni. Kita diciptakan sebagai citra Allah. Kita diciptakan dengan identitas dan eksistensi yang sepenuhnya bergantung kepada sesuatu yang kekal dan tetap, yaitu Allah Sang Pencipta Mutlak. Allah menciptakan untuk mengungkapkan diri-Nya; kita menciptakan untuk menyatakan respon kita atas kasih Allah.

2. Allah tidak pernah menciptakan dua kristal salju yang identik. Ia juga memenuhi dunia dengan flora-fauna yang sangat beragam. Berarti seni non-representasionalistis, seperti seni abstrak yang tidak

42 Harold M. Best, "God as Creator" dalam Reality of Christian Learning (Minnesota: Christian University Press, 1987), 247. 
menggambarkan apapun juga di alam adalah sah. Tetapi memang hal ini tak dapat dilakukan secara sempurna, sekeras-kerasnya sang seniman mencoba untuk tidak menggambarkan apapun, tetap saja ia melakukan representasi dalam seninya, karena memang manusia tidak dapat melakukan creatio ex nihilo.

3. Ciptaan Allah penuh dengan representasi. Seorang anak mirip dengan orang tuanya. Sebuah keluarga biasanya memiliki kesamaan-kesamaan bawaan tertentu. Dan dalam skala besar, mahluk yang satu spesies memiliki ciri-ciri khas tertentu, demikian juga dengan unsur-unsur kimia. Jadi seni representasi adalah sah juga; orang boleh-boleh saja menghasilkan karya seni yang menggambarkan sesuatu secara sangat realistis selama ia tidak kehilangan sentuhan subjektifnya.

4. Seperti dikatakan dalam poin ke-2, Tuhan tidak pernah melakukan penggandaan identik. Tiap karya seni pasti memiliki ciri personal yang khas. Jadi hasil karya yang identik-replikatif seperti peng-copy-an karya seni orang lain tak dapat dikatakan sebuah karya seni. Saat kita memainkan sebuah komposisi musik, pastilah kita memberikan satu sentuhan pribadi pada musik yang terdengar. Usaha untuk meniru sepersis mungkin gaya permainan dan sentuhan pribadi orang lain dalam seni tak dapat dikatakan sebagai seni lagi. Ia hanya seorang tukang main musik, bukan musisi.

5. Ciptaan Tuhan membeberkan variasi maha ragam, tetapi tetap mencerminkan satu style penciptaan yang khusus. Kita dapat saja 
membubuhkan (biasanya secara tak sadar) suatu gaya pribadi dalam menciptakan aneka ragam karya seni.

6. Ciptaan Tuhan menyatukan Keindahan dan Fungsi. Ini mengakhiri perdebatan antara "yang indah" dan yang "fungsional." Pandangan l'art pour l'art yang telah mengebiri segi fungsional dari suatu karya seni dan memandang rendah karya seni yang memiliki suatu fungsi tidak dapat dibenarkan. Juga pandangan kaum pragmatis yang kurang mempedulikan faktor estetis tidak sesuai dengan etika penciptaan Tuhan. Tuhan menciptakan tubuh manusia yang sangat-sangat estetis tetapi sekaligus sangat fungsional. Tak ada desain buatan manusia yang melampaui keindahan tangan manusia, tetapi juga tak ada desain buatan manusia yang melebihi keserbagunaan, kekuatan, keandalan, dan efisiensi tangan manusia. Desain ajaib Tuhan ini dapat dipakai untuk menghasilkan lukisan yang indah, musik yang menakjubkan, tetapi juga sekaligus dapat dipakai untuk mengangkat beban berat atau melakukan operasi bedah saraf yang menuntut tingkat presisi tinggi.

7. Alam ciptaan tidak mencerminkan adanya hirarki keindahan. ${ }^{43}$ Tuhan menciptakan kecoak dengan sangat indah (walaupun banyak yang jijik) -

43 Pernyataan ini mungkin memerlukan kualifikasiuntuk menghindarkannya dari kesalahpahaman seolah-olah saya sedang mengatakan bahwa tidak ada perbedaan nilai estetis antara karya Bach dan Bieber, antara sungai-sungai di Guilin dan Grogol. Proposisi No. 7 dikenakan kepada karya Tuhan, bukan kepada karya manusia, yang sesungguhnya adalah respon kita kepada hukum Allah.Karya Allah tak dapat salah, Ia tak dapat berlawanan dengan hukum-Nya sendiri.Sedangkan tentu saja respon kita dapat mencerminkan ketaatan dan pemberontakan kita pada hukum Allah.Tidak ada yang buruk ataupun jahat yang berasal dari Tuhan. Tetapi tentu saja ada yang salah dengan musik Bieber (bahkan Bach juga!), seperti juga ada yang salah di dalam sungai-sungai kita - entah di dalam abai kita pada air yang menyebabkan bau busuk dan pencemaran sungai, atau mungkin juga pada penindasan yang kita lakukan kepada orang-orang lemah yang kita anggap dapat mencemari pemandangan dan 
tidak kalah indah dibandingkan dengan sekuntum anggrek. Bahkan kadang-kadang faeces manusia pun dapat mengambil rupa yang sangat artistik. Tuhan menciptakan galaksi maha besar seindah Ia menciptakan sel-sel mikroba.

Dengan demikian daya kreasi kita seharusnya dipakai untuk mengekspresikan rasa takjub dan syukur kita atas segala pekerjaan Allah yang besar dan melimpah dengan anugerah. Seorang seniman Kristen seharusnya tidak menciptakan sesuatu demi mencipta itu sendiri, tidak melakukan pemberontakan atas pola lama demi pemberontakan itu sendiri, tidak memuja keindahan alam, keindahan karya seni, maupun kejeniusan seniman demi hal-hal itu sendiri, tetapi hendaknya itu dilakukan sebagai respon kita atas anugerah Allah yang besar, dan sebagai respon penyembahan kita atas kemahadahsyatan Allah. Apresiasi keindahan bersumber dari ketakjuban kita atas keindahan Tuhan, kesadaran kita akan kemahaagungan dan kebesaran kasih-Nya, sedangkan kreasi seni adalah ekspresi atas ketakjuban, kegentaran, dan cinta kita pada Tuhan.

\section{Kesimpulan}

Persepsi kita tentang keindahan sangat ditentukan oleh konsep estetika yang kita terima. Konsep estetika ini juga akan menentukan bentuk dan perkembangan karya seni yang dihasilkan seorang seniman. Sepanjang

menghambat kenaikan nilai properti. Dengan demikian, tentu saja ada perbedaan nilai pada hasil karya Bach dan Bieber, Igor Stravinsky dan Inul, bahkan Ciliwung dan Cilember - tetapi pembedaan nilai ini bukan berasal dari hirarki keberadaan itu sendiri (yang misalnya kita jumpai pada cara-cara orang di Abad Pertengahan melihat dunia, yang berhutang kepada ontology of Beings dari Plotinus), melainkan disebabkan oleh perbedaan pada respon-respon manusia pada hukum Allah (dalam hal ini hukum Allah pada aspek estetik). 
sejarah konsep estetika terus menerus berubah sesuai dengan perkembangan dunia dan filsafat pada masanya. Perkembangan filsafat sangat menentukan konsep estetika pada suatu zaman, dan akhirnya sangat menentukan ciri karya seni pada zaman tersebut. Perkembangan konsep estetika, yang diikuti juga oleh hasil karya seninya, bergerak dari sesuatu yang konkret menuju hasil karya seni yang semakin abstrak (nonrepresentatif). Ini sesuai dengan filsafat Hegel menggambarkan pergerakan sejarah menuju titik akhir dari dialektika: realisasi dari Roh Absolut. Perkembangan kesenian ke arah yang semakin abstrak ini akhirnya jatuh pada konsep estetika yang absurd. Kreativitas didefinisikan sebagai usaha manusia untuk memberontak terhadap tatanan baku yang sudah ada. Pemberontakan demi pemberontakan itu sendiri berakar dari keinginan manusia untuk menjadi "seperti Allah" dan re-creating the creation. Ketidakpuasan manusia akan ciptaan mungkin bersumber juga dari ketidakmengertian manusia akan kenyataan kejatuhan manusia yang telah menyeret seluruh ciptaan. Dunia yang dikatakan van Gogh sebagai "lukisan Tuhan yang gagal," dari perspektif Kristiani adalah suatu 'kejatuhan' dari ordo Penciptaan yang baik. Ada bagian tanggung jawab manusia untuk keburukan itu. Usaha manusia untuk menciptakan kembali dunia yang lebih baik dalam kanvas, tanpa dibarengi pengertian bahwa hanya Tuhan sendiri yang dapat menebus ciptaan dari kejatuhannya, akhirnya harus berakhir tragis dengan munculnya aliran-aliran yang bersifat nihilis dan selfdestructive seperti Dadaisme dan Neo-Dadaisme. Hal ini mungkin juga tercermin dalam rasa frustrasi mendalam yang dialami van Gogh sepanjang kehidupan dewasanya. Konsep estetika Ibrani sangat berbeda dengan 
konsep estetika yang dihasilkan oleh bangsa-bangsa lain. Orang-orang Ibrani tidak mengenal konsep estetika secara abstrak seperti bangsa Yunani. Keindahan bagi orang Ibrani tidak pernah berdiri sendiri. Keindahan adalah cerminan kekudusan dan kemuliaan Tuhan yang disingkapkan kepada umat-Nya. Karena media kata-kata (verbal) lebih akurat dalam mengekspresikan pengalaman religius bangsa Ibrani, dan adanya bahaya media visual yang ambigu untuk menimbulkan penyembahan berhala, media visual kurang berkembang dalam sejarah budaya Ibrani. Kesenian Kristen yang baik haruslah mempertimbangkan normativitas dari ‘hukum Tuhan' dalam proses penciptaannya. Jika kita melihat proses penciptaan alam semesta, kita akan melihat solusi dari berbagai dilema yang dialami oleh para filsuf sepanjang zaman. Misalnya, Tuhan tidak mencipta untuk membuktikan diri, tapi menyatakan diri. Tuhan tidak pernah membuat ciptaan yang identik, jadi seni non-representatif itu sah, tetapi sekedar meniru karya orang lain adalah tidak sah. Ciptaan penuh dengan representasi, yaitu hal-hal yang memiliki kemiripan, misalnya ayah-anak, sehingga seni representatif yang konservatif itu tidak dapat dikatakan kurang kreatif. Ciptaan yang beragam itu tetap mencerminkan satu style yang unik dari Tuhan, jadi subjektifitas dalam seni penting juga.Tuhan tidak pernah memisahkan fungsi dari estetika; Ia menciptakan tubuh manusia superior baik secara fungsional maupun estetis. Terakhir, Tuhan tidak membuat hirarki seni; semua ciptaan sama-sama diciptakan dengan ketelitian tinggi. Dari lalat sampai gajah, dari atom sampai galaksi samasama menggemakan keindahan, kemuliaan dan kekudusan Penciptanya. ${ }^{44}$

44 Selaras dengan catatan kaki no. 43, secara positif, karya seni yang selaras dengan hukum 
Tuhan akan menjadi berkat bagi umat manusia melalui pembukaan nuansa-nuansa ciptaan yang terjadi ketika orang berjumpa dengan karya tersebut. Kita dapat mengingat bagaimana puisi-puisi di dalam Alkitab (Mazmur, Ratapan, Kidung Agung, dst) mencelikkan mata kita untuk dapat melihat lebih banyak alasan untuk mengucap syukur, memuji Tuhan, memuja Tuhan, dan berharap kepada-Nya di dalam kesesakan. Tetapi di sisi yang lain, ada juga kesenian-kesenian tertentu yang menutup mata batin kita dari kemuliaan Tuhan, mungkin dengan menerbitkan aneka keserakahan, ketakutan yang salah, dan hawa nafsu yang tidak patut, yang menyesaki pikiran dan hati kita sedemikian sehingga yang baik, yang indah, dan yang patut dipuji tidak dapat berdiam dalam kehidupan kita secara melimpah. 